\title{
1 Is altered behavior linked to cellular energy regulation in a freshwater mussel (Elliptio
}

\section{2 complanata) exposed to triclosan?}

3 Christopher G. Goodchild ${ }^{\mathrm{a}, \mathrm{b}^{*}}$, Markus Frederich ${ }^{\mathrm{a}}$, Stephan I. Zeeman ${ }^{\mathrm{a}}$

4

5 aDepartment of Marine Sciences, University of New England, 11 Hills Beach Rd., Biddeford,

6 Maine 04005, USA

$7 \quad{ }^{\mathrm{b}}$ Department of Integrative Biology, Oklahoma State University, 501 Life Sciences West,

8 Stillwater, Oklahoma 74078, USA

9

10 Running title: Is altered behavior linked to cellular energy regulation?

11

12 ms. has 29 pages, 2 tables, 4 figures, 2 suppl. figures

13

14 *Corresponding author: Christopher G. Goodchild

15 Email: christopher.goodchild@ okstate.edu; Phone \#: 1 (918) 640-0432

16

17 MF: $\underline{\text { mfrederich@une.edu }}$

18 SIZ: szeeman@une.edu

19

20 


\section{ABSTRACT}

22 Environmental stress may alter the bioenergetic balance of organisms by resulting in greater

23 energy investment into detoxification processes, which diverts energy from other biological

24 functions. Here, we examine responses to triclosan (TCS) exposure in a freshwater mussel across

25 multiple biological levels: behavioral (e.g., burrowing and movement activity), organismal (e.g.,

26 metabolic rate and heart rate), and subcellular (e.g., gene expression and protein

27 abundance/activity). At the subcellular level, we employed both energetic (i.e., AMP-activated

28 protein kinase (AMPK)) and traditional (i.e., heat shock protein (HSP70), superoxide dismutase

29 (SOD), glutathione-S-transferase (GST)) biomarkers. We found a significant reduction in

30 burrowing and movement behaviors, a 1.8-fold increase in total-AMPK protein abundance, and a

312.8 -fold increase in AMPK activity after $21 \mathrm{~d}$. GST activity increased after $4 \mathrm{~d}$, but not after $21 \mathrm{~d}$.

32 Our findings suggest TCS exposure results in an energetic tradeoff between detoxification at the

33 cellular level and whole-animal activity.

34

35 Keywords: triclosan, bivalves, AMPK, bioenergetics, biomarkers, behavior, energy allocation 


\section{1. INTRODUCTION}

37 Pharmaceuticals and personal care products (PPCPs) have been flagged as high priority pollutants

38 because they pose potential ecological hazards at low concentrations (Harada et al., 2008; Murray

39 et al., 2010; Mearns et al., 2013). Triclosan (TCS; 5-chloro-2-(2,4-dichlorophenoxy) phenol) is a

40 broad-spectrum antimicrobial agent found in numerous PPCPs at concentrations typically ranging

41 between $0.1 \%$ to $0.3 \%$ active ingredient by weight (Sabaliunas et al., 2003). Of the estimated 300

42 tons of TCS used annually in the USA, 85\% is contained within PPCPs, which are typically

43 disposed of through residential drains (Bedoux et al., 2012). Consequently, TCS is commonly

44 detected in municipal wastewater treatment facility influent as well as effluent (McAvoy et al.,

45 2002; Antoniou et al., 2009; Bell et al., 2011; Bedoux et al., 2012 and references therein). Global

46 environmental inputs of TCS exceed $600,000 \mathrm{~kg} \mathrm{yr}^{-1}$ and could be as high as 10,000,000 $\mathrm{kg} \mathrm{yr}^{-1}$

47 (TSCA, 2003). Environmental concentrations of TCS vary temporally and among water bodies,

48 with surface water TCS concentrations ranging from $<1.0-2,300 \mathrm{ng} \mathrm{L}^{-1}$ (see reviews by Barber

49 et al., 2000; Kolpin et al., 2002; Bedoux et al., 2012; Dhillon et al., 2015). The continuous

50 introduction of TCS into aquatic environments makes it a pseudo-persistent pollutant that is

51 bioavailable and potentially harmful to aquatic organisms (Coogan and La Point, 2008; Gatidou

52 et al., 2010; Kookana et al., 2013).

53 Several studies have demonstrated that exposure to TCS can alter biochemical processes

54 in bivalves. For instance, acute TCS exposure increases activities of detoxification enzymes

55 (Binelli et al. 2009a,b,2011; Matozzo et al., 2012a), like glutathione-S-transferase (GST) and

56 superoxide dismutase (SOD). SOD and GST are phase I and phase II detoxification enzymes,

57 respectively, and are typically used to evaluate cellular oxidative stress. Phase I enzymes

58 oxygenate xenobiotics, producing either polar metabolites that are directly excreted, or substrates

59 for phase II enzymes. Phase II enzymes transform xenobiotics into compounds that may be

60 incorporated by an organism (Gregus, 2013). TCS can also up-regulate heat shock proteins,

61 which act as protective scaffolding proteins (Riva et al. 2012). Additionally, recent in vitro 
62 experiments with mammalian cell lines suggest TCS acts as a mitochondrial uncoupler and

63 reduces ATP production (Weatherly et al., In press), though this mode of action has not been

64 investigated in bivalves. Although these and other studies (see Canesi et al., 2007; Cortez et al.,

65 2012; Matozzo et al., 2012b; Falfushynska et al., 2014) provide strong support for TCS causing

66 disruption of cellular and biochemical processes, it is unclear whether cellular responses are

67 relevant at higher levels of organization (e.g., organismal or population level; Maltby, 1999;

68 Forbes et al., 2006). Indeed, recently there has been greater effort to elucidate adverse outcome

69 pathways by establishing linkages across levels of biological organization (Ankley et al. 2010).

70 For this reason, we examined energetic effects of TCS exposure in mussels at multiple levels of

71 biological organization

72 Energy is a common currency that spans all levels of biological organization (Brown et

73 al., 2004), thus a bioenergetics approach to evaluating toxicity may help link subcellular effects

74 to effects at higher levels of biological organization. According to the dynamic energy budget

75 hypothesis (reviewed in Kooijman et al., 2009), organisms are typically energy-limited by

76 resources in their environment and metabolic capacity, and must allocate available resources

77 between various biological functions (i.e., reproduction, activity, growth, maintenance).

78 Environmental stress can alter the allocation of resources due to increased energy requirements

79 for repair costs or reduced energy (i.e., ATP) producing potential (Selye, 1950; McEwen and

80 Wingfield, 2003; Romero et al., 2009). As a result of cellular energy depletion, metabolically

81 costly processes, like movement and reproduction, may be impaired (Sokolova et al., 2012).

82 Therefore, biomarkers of cellular energy status may serve as informative predictors of effects at

83 higher levels of biological organization (De Coen and Janssen, 2003).

84 Energy homeostasis at the cellular level is regulated in part by the heterotrimeric protein

85 AMP-activated protein kinase (AMPK), which is ultrasensitive to changes in ATP availability

86 (Hardie et al., 2006). During an energetic challenge, AMPK acts to maintain ATP concentrations

87 by promoting ATP-producing pathways (e.g., glucose uptake, glycolysis, fatty acid beta- 
88 oxidation) and, in tandem, inhibiting ATP-consuming pathways (e.g., protein synthesis, fatty acid

89 synthesis, glycolysis synthesis; Hardie et al., 2006). The regulatory function of AMPK is

90 essential to maintaining energy homeostasis because the $\Delta G$ from the hydrolysis of ATP to ADP

91 is dependent on cellular ATP:ADP ratios. For this reason, organisms can be energetically stressed

92 without observable changes in ATP concentration. In mammals, AMPK is comprised of a

93 catalytic subunit (AMPK $\alpha$ ) and two regulatory subunits (AMPK $\beta$, AMPK $\gamma$; Carling et al., 1989).

94 Although the structure of AMPK has not been validated in mussels, AMPK is highly conserved

95 between different eukaryotes (Hardie, 2007), and we have therefore assumed this kinase has a

96 heterotrimeric structure in mussels as well (Guevelou et al., 2013; Jost et al., 2015). Recently, we

97 found evidence for AMPK as a sensitive energetic biomarker to municipal effluent exposure in

98 situ (Goodchild et al., 2015), but it is unknown whether this is associated with effects at higher

99 levels of biological organization.

100 The present study evaluated energetic effects caused by subchronic TCS exposure in the

101 freshwater mussel Elliptio complanata (Bivalvia: Unionoida; hereafter referred to simply as

102 mussels) across multiple biological levels: behavioral (e.g., burrowing and movement activity),

103 organismal (e.g., metabolic rate, heart rate), and subcellular (e.g., protein abundance/activity and

104 gene expression). At the subcellular level, we examined AMPK as a biomarker of cellular energy

105 status, heat shock protein 70 (HSP70) as an indicator of general stress, and antioxidant enzymes

106 (i.e., SOD, GST) as indicators of oxidative stress. We hypothesized that the energetic cost of

107 detoxification disrupts cellular energy homeostasis, resulting in increased AMPK levels and an

108 energetic tradeoff with other biological processes.

\section{2. METHODS}

\section{$110 \quad 2.1$ Animal Collection and Maintenance}

111 Mussels $(60 \mathrm{~mm} \pm 5)$ were collected in August 2013 from the Sheepscot River ME, USA

112 (44.180695, -69.626566), which has been annually monitored from 1998-2012 and has received a

113 high water-quality rating, determined by macroinvertebrate diversity and water chemistry (see 
114 Tsomides et al., 2013). Collected mussels were immediately transported to the University of New

115 England's Marine Science Center in plastic bags of river water. Mussels were allowed to

116 acclimate for 3 weeks in a $500 \mathrm{~L}$ tank with continuously aerated dechlorinated tap water and 90\%

117 water renewals occurring every other day. During acclimation, mussels were fed PhytoPlex

118 Phytoplankton (Kent Marine, Walnut Creek, CA, USA) ad libitum. Throughout acclimation and

119 TCS exposure, water conductivity $(100 \pm 20 \mathrm{mS})$, temperature $\left(18 \pm 2^{\circ} \mathrm{C}\right)$, dissolved oxygen

$120(9.27 \pm 0.41 \mathrm{mg} / \mathrm{L})$, and $\mathrm{pH}(7.14 \pm 0.37)$ were monitored, and photoperiod was maintained at

121 12:12 D:L.

$122 \quad 2.2$ Experimental Design

123 TCS exposures occurred in $80 \mathrm{~L}$ glass aquaria (3 L per mussel) at nominal concentrations of 300 ,

124 600, or $900 \mathrm{ng} \mathrm{L}^{-1}$ (Sigma-Aldrich, CA, USA). Exposure concentrations were maintained with

$125100 \%$ water renewals every $48 \mathrm{~h}$. We did not measure TCS concentrations analytically;

126 nonetheless, our methods are consistent with previously conducted studies that employed similar

127 protocols (e.g., Binelli et al., 2009b; Gatidou et al., 2010; Riva et al., 2012; Matozzo et al.,

128 2012a). Additionally, Kookana et al. (2013) investigated TCS bioconcentration in a marine

129 mussel (Mytilus galloprovincialis; TCS concentration: $100 \mathrm{ng} \mathrm{L}^{-1}$; density: 4 L per mussel) and

130 found only a $20 \%$ reduction in TCS after $72 \mathrm{~h}$. Thus, although some caution should be used when

131 interpreting our results, there is strong evidence to suggest a $48 \mathrm{~h}$ renewal period is sufficient to

132 maintain TCS concentrations. A stock solution of $1 \mathrm{~g} \mathrm{TCS} \mathrm{L}^{-1}$ dimethyl sulfoxide (DMSO) was

133 further diluted in decholorinated tap water for a final concentration of $5 \mathrm{mg} \mathrm{TCS} \mathrm{L}{ }^{-1}$. DMSO was

134 used as a carrier molecule to deliver TCS to tissue. The control group was exposed to DMSO and

135 in all treatments DMSO concentrations were $<0.0001 \% \mathrm{v} / \mathrm{v}$ DMSO by water. Mussels were fed 2

$136 \mathrm{~h}$ prior to each water renewal during TCS exposure. Our experimental design allowed us to

137 investigate responses at multiple levels of organization, but in doing so, precluded us from

138 measuring all responses for each individual. Consequently, behavior, metabolic rate, heart rate,

139 and subcellular effects were measured independent of each other (i.e., tissue of mussels from the 
140 behavior assay was not analyzed for subcellular endpoints). All protein and mRNA effects were

141 assessed for the same individual. Responses were measured after 4 and $21 \mathrm{~d}$ except behavior,

142 which was only measured after $21 \mathrm{~d}$.

\section{$143 \quad 2.3$ Behavior}

144 Burrowing and movement assays were conducted according to Waller et al. (1999) with slight

145 modifications. Briefly, prior to TCS exposure, identification buoys were attached to the posterior

146 slope of the left valve with fishing line, dental wax, and super glue, allowing identification of

147 completely burrowed individuals. After TCS exposure, mussels $(\mathrm{n}=10$ per treatment) from all

148 treatment groups were transferred to a single fiberglass tank ( $1.83 \mathrm{~m}$ long, $0.91 \mathrm{~m}$ wide, and 0.41

149 m deep) with a 0.15 m-deep layer of sand and TCS-free dechlorinated tap water. Mussels were

150 placed on the substrate and location, given by the umbo, was recorded by dropping a weighted

151 line through an overlaid plastic grid (cell size $=1.5 \mathrm{~cm}$ ). Burrowing and movement behaviors

152 were recorded at $1,2,6,12,24,48,72,96,120,144$, and $168 \mathrm{~h}$, and mussels were described as

153 inactive, burrowed, or relocated (i.e., movement event). In nearly all instances, righting occurred

154 with burrowing or relocation events and was not differentiated in this study. In mussels, activity

155 is an ordered process, and relocation is preceded by righting and burrowing (Waller et al. 1999).

156 For this reason, slight movements $(<7.5 \mathrm{~cm})$ occurring prior to burrowing were disregarded, as

157 such movements are an artifact of the burrowing process and not a true relocation event.

$158 \quad 2.4$ Metabolic rate

159 Basal metabolic rate was determined by closed vessel respirometry. Mussels $(n=7$ per treatment)

160 were placed in sealed respirometry jars, and oxygen concentrations were taken in triplicate at 5

161 min intervals using an OxySense ${ }^{\circledR}$ system and an oxygen sensitive OxyDot ${ }^{\circledR}$. To avoid stress

162 from hypoxic conditions, mussels were removed from respirometry jars before oxygen

163 concentration dropped below $85 \%$ of initial concentration.

1642.5 Heart rate 
165 Heart rate ( $\mathrm{n}=7$ per treatment) was measured by impedance pneumography (see Braby and

166 Somero, 2006). Briefly, two $1.8 \mathrm{~mm}$ holes were made on the posterio-dorsal edge of the right

167 valve next to the pericardial cavity using a Dremel tool. Silver electrodes (40 AWG wire, with 3

$168 \mathrm{~mm}$ of tip exposed) were inserted into each hole and held in place with superglue and dental wax.

169 Heart rate was monitored for 3-5 min by converting an analog impedance signal to a voltage

170 signal (UFI, Impedance Converter model 2991, Morro Bay, CA, USA) and recorded using a data

171 acquisition system (ADInstruments, PowerLab, Colorado Springs, CO, USA).

$172 \quad 2.6$ Protein abundance and activity

173 Protein abundance and activity were measured using previously established protocols (see

174 Frederich et al., 2009; Jost et al., 2012). Hepatopancreatic tissue ( 1g) was isolated from mussels

175 ( $\mathrm{n}=5$ per treatment), snap frozen in liquid nitrogen, and stored at $-80{ }^{\circ} \mathrm{C}$. To prevent

176 dephosphorylation of enzymes, tissue homogenization occurred in a phosphate buffer containing

177 a cocktail of protease inhibitors (4-(2-aminoethyl)benzenesulfonyl fluoride hydrochloride at 104

$178 \mathrm{mM}$, aprotinin at $80 \mu \mathrm{M}$, bestatin at $4 \mathrm{mM}$, E-64 at $1.4 \mathrm{mM}$, leupeptin at $2 \mathrm{mM}$ and pepstatin $\mathrm{A}$ at

$1791.5 \mathrm{mM}$; Sigma-Aldrich, St Louis, MO, USA). Homogenized tissues were centrifuged at $1700 \times \mathrm{g}$

180 for $10 \mathrm{~min}$; the supernatant was collected and centrifuged again at $21000 \mathrm{x} g$ for $40 \mathrm{~min}$. The

181 Bradford method was used to determine total protein concentration for each sample (Bradford $e t$

182 al., 1976).

183 Relative quantities of total-AMPK, phosphorylated-AMPK (i.e., AMPK-activity), and

184 total HSP70 were determined by western blotting. Proteins from homogenate $(50 \mu \mathrm{g})$ were

185 separated on a $10 \%$ polyacrylamide/SDS gel at $180 \mathrm{~V}$ for $30 \mathrm{~min}$ and transferred to a

186 nitrocellulose membrane at $70 \mathrm{~V}$ for $2 \mathrm{~h}$. The membrane was then blocked with $3 \%$ non-fat dry

187 milk. The proteins were visualized with primary mouse anti-HSP70 (Sigma, St Louis, MO, USA;

188 product no.: H5147), rabbit anti-AMPK (Millipore, Billerica, MA, USA; product no.: 07-681)

189 and rabbit anti-pT172 (AmpliCruz, Santa Clara, CA, USA; product no.: sc-33524) antibodies, and

190 quantified on a LiCor Odyssey Imaging system with secondary donkey anti-rabbit antibodies and 
191 goat anti-mouse antibodies (Sigma-Aldrich). Mouse anti-actin antibodies (Sigma-Aldrich) were

192 used as a loading control. Protein abundance was determined by densitometric analysis using

193 ImageJ software (http://imagej.nih.gov/; see Perez and Pascue, 2013) relative to controls

194 (Heidebrecht et al., 2009).

195 Enzyme activities of SOD and GST were measured in duplicate according to McCord

196 and Fridovich (1969) and Habig et al. (1974), respectively. Reactions were carried out in a

197 phosphate buffer (Sigma-Aldrich) using standard cuvettes and a Beckman Coulter 700 Series UV

198 spectrophotometer. SOD competes with cytochrome $\mathrm{C}$ for superoxide radicals produced

199 enzymatically by hypoxanthine and xanthine oxidase. SOD activity was measured as inhibition of

200 cytochrome $\mathrm{C}$ reduction at $550 \mathrm{~nm}$ for $5 \mathrm{~min}$. GST activity was determined by the conjugation of

201 glutathione and dinitrobenzene facilitated by GST and monitored at $330 \mathrm{~nm}$ for 5 min.

$202 \quad 2.7$ mRNA Expression

203 Relative mRNA concentration of AMPK $\gamma$, HSP70, SOD, and GST mRNA were

204 quantified by semi-quantitative real-time PCR according to Frederich et al. (2009). Briefly,

205 hepatopancreatic tissue ( 1 g) was isolated from the same individuals used for protein analysis.

206 Tissue was placed in RNAlater ${ }^{\circledR}$ Solution (Life Technologies, Carlsbad, CA, USA), and stored at

$2074^{\circ} \mathrm{C}$ until analysis. Total RNA was purified using the Total RNA Isolation System (Promega,

208 Madison, WI, USA). Tissue was homogenized in RNA denaturing solution using a Bullet Blender

209 and RNAase-free zirconium oxide beads (Next Advance, Averill Park, NY, USA). Homogenate

210 was centrifuged at $1700 \mathrm{x} g$ for $10 \mathrm{~min}$. The supernatant was collected, acidified with sodium

211 acetate, extracted with phenol-chloroform, and centrifuged at $21000 \mathrm{x} g$ for $40 \mathrm{~min}$. RNA was

212 precipitated overnight in isopropanol at $-20^{\circ} \mathrm{C}$. After centrifugation, the pellet was washed,

213 resuspended in RNAase-free water, and stored at $-80^{\circ} \mathrm{C}$ until analysis. $1.8 \mu \mathrm{g}$ of total RNA

214 (260/280 absorbance ratio: $2.0 \pm 0.1)$ were reverse transcribed using the Super-Script III First

215 Strand Synthesis System (Invitrogen, Carlsbad, CA, USA). Alien RNA (Agilent, La Jolla, CA,

216 USA) was added as an external control for alerting reverse transcription inhibition and 
217 normalizing PCR efficiency (Huggett et al., 2005). Gene targets were amplified with primers

218 developed by Goodchild et al. (2015; Table 1) and an Agilent Brilliant SYBR Green qPCR Kit

219 (Agilent, La Jolla, CA, USA) on a Stratagene MX3005s instrument. After 40 cycles with an

220 annealing temperature of $53^{\circ} \mathrm{C}$ for AMPK $\gamma$ and HSP70, or $55^{\circ} \mathrm{C}$ for SOD and GST, a melting

221 curve analysis confirmed that only one DNA product was amplified per gene target.

\section{2.8 Statistical Analysis}

223 To analyze behavioral data, two statistical analyses were employed to describe (1) time-

224 dependent intensity of whole-animal performance and (2) distribution of behavioral responses

225 within treatment groups. Use of the Cox proportional hazard model (Cox, 1972) is increasingly

226 common in behavioral ecology studies in general (e.g., Cole and Quinn, 2014) and has been used multiple

227 times to specifically assess mussel burrowing performance (e.g., Waller et al., 1999; Hazelton et al., 2014).

228 This modeling approach generates a proportional hazard also described as intensity of an event

229 given a condition. In our case, we used this modeling approach to describe intensity of burrowing

230 and movement following TCS exposure. This approach to analyzing mussel behavioral data is

231 appropriate because some individuals did not conduct behaviors during the study duration and

232 therefore the data are considered right-censored, which the proportional hazard model

233 accommodates (see Waller et al., 1999; Hazelton et al., 2014); the alternative approach is to

234 remove non-responding individuals from the dataset and use a group means statistical test (e.g.,

235 Flynn et al., 2013). The parameter estimates are generated as a proportional likelihood of an event

236 occurring relative to the control group. In a second analysis, we evaluated the overall effect of

237 TCS on mussel activity, regardless of when events occurred. To do so, we used an ordered logit

238 model to test if TCS affects mussel vigor, with the assumption that increasing activity (inactivity

239 < burrowing < relocation) indicated greater vigor (Waller et al., 1999).

240 A repeated-measures analysis of variance was used to analyze heart rate data (standard

241 assumptions were tested and Mauchly's test confirmed that the model did not violate the

242 assumption of sphericity $(\mathrm{p}=0.89))$. Metabolic rate and GST and SOD activity were analyzed 
243 using two-way analysis of variance. Western blot and qPCR data were quantified relative to the

244 controls of the respective sampling day (i.e., $4 \mathrm{~d}$ or $21 \mathrm{~d}$ ), therefore mRNA concentrations and

245 protein abundance of AMPK and HSP70 were analyzed via one-way analysis of variance within

246 sampling time-points. All statistical tests were done with R Version 3.0.2 (R Core Team, 2013)

247 using RStudio@ Version 0.97.551 interface (RStudio Team, 2015).

\section{3. RESULTS}

\subsection{Behavior}

250 TCS exposure impaired burrowing and movement behaviors (Fig. 1). The Cox proportional

251 hazard model revealed that mussels exposed to $900 \mathrm{ng} \mathrm{L}^{-1} \mathrm{TCS}$ concentration had a lower

252 likelihood of burrowing $(\mathrm{p}=0.03)$ and relocating $(\mathrm{p}=0.02)$ relative to the control group (Table

253 2). Activity decreased in mussels exposed to TCS (Fig. 1b), and the time-independent ordered

254 logit model provided further evidence that TCS exposure decreases mussel vigor $(\mathrm{p}=0.01)$.

\subsection{Protein abundance and activity}

256 After $21 \mathrm{~d}$ of exposure to TCS there was a 1.8-fold increase in total-AMPK $\alpha$ (p = 0.04; Fig. 2a),

257 and mussels in $900 \mathrm{ng} \mathrm{L}^{-1}$ group had a 2.8-fold increase in AMPK-activity ( $\mathrm{p}=0.02$; Fig. 2b).

258 There was no difference in HSP70 concentrations at either sampling point (Fig. 2c). GST activity

259 was significantly increased after $4 \mathrm{~d}$ in the $300 \mathrm{ng} \mathrm{L}^{-1}(\mathrm{p}=0.02)$ and $900 \mathrm{ng} \mathrm{L}^{-1}(\mathrm{p}=0.03)$ groups,

260 but not in the $600 \mathrm{ng} \mathrm{L}^{-1}$ group (Fig. 3a). However, there was no difference in GST or SOD

261 activity after $21 \mathrm{~d}$ (Fig. 3).

2623.3 mRNA Expression

263 There was no change in AMPK mRNA expression after $4 \mathrm{~d}$. However, after $21 \mathrm{~d}$, the $900 \mathrm{ng} \mathrm{L}^{-1}$ 264 group had elevated AMPK mRNA expression relative to the control, but this difference was not 265 significant ( $\mathrm{p}=0.06$; Fig. 4a). GST mRNA expression trended upward after $4 \mathrm{~d}$, though this trend 266 did not achieve statistical significance $(\mathrm{p}=0.06)$ and there were no differences after $21 \mathrm{~d}$ (Fig.

267 4d). mRNA expression of HSP70 (Fig. 4b) and SOD (Fig. 4c) were unchanged.

\subsection{Heart rate and oxygen consumption}


269 At the organismal level, there were no significant differences $(\mathrm{p}>0.05)$ in resting metabolic rate

270 (Fig. S1) or heart rate (Fig. S2) after 4 and $21 \mathrm{~d}$ of TCS exposure. Heart rate remained unchanged

271 at $8.9 \pm 0.6$ beats per minute, and oxygen consumption stayed constant at $0.27 \pm 0.07 \mu$ mol $\mathrm{O}_{2}$

$272 \min ^{-1} \mathrm{~g}^{-1}$.

\section{4. DISCUSSION}

274 Environmental contaminants can have a wide range of physiological effects that vary depending

275 on level of biological organization and exposure duration. In this study, we examined effects

276 across multiple scales and after acute and subchronic exposure durations. Our data suggest TCS

277 exposure reduces burrowing and relocation, which are energetically costly behaviors essential to

278 mussel ecology. During high river discharge or other disturbances, mussels can become dislodged

279 and must reorient themselves by righting, burrowing, and relocating (Waller et al., 1999). An

280 inability to perform these actives may increase predation risk (Bowers et al., 2005), diminish

281 reproductive success (Amyot and Downing, 1997,1998; McMahon and Bogan, 2001), and

282 decreases drought tolerance (Gough et al., 2012). Moreover, reduced mussel activity may impact

283 the broader benthic community because disoriented mussels are unable to conduct important

284 ecological services such as water column filtration (Caraco et al., 2006; Loayza-Muro and Elias-

285 Letts, 2007; Allen and Vaughn, 2009), aeratation of benthic sediments through bioturbation

286 (Loher et al., 2004), and biodeposition of nutrient dense material (Vaughn and Hakenkamp, 2001;

287 Spooner and Vaughn, 2012). Because burrowing and movement behaviors are vital to mussels'

288 reproductive strategies and their ability to perform ecological services, energy stress may have

289 proximate (i.e., individual fitness) and ultimate (i.e., population health and community stability)

290 effects (Calow, 1989).

291 In a variety of taxa, energetically demanding activities are associated with cellular energy

292 stores (e.g., Carmi et al., 1992, Milligan, 1996; Richards et al., 2002); therefore a reduction in

293 burrowing and movement may indicate that TCS exposure causes a reallocation or depletion of

294 cellular energy (Sokolova et al., 2012). However, we did not detect any differences in resting 
295 oxygen consumption or heart rate at the organismal level, suggesting the energetic cost of TCS 296 exposure is not compensated for by an increase in resting metabolic rate. Palenske et al. (2010) 297 report increased heart and metabolic rates in frog larvae exposed to TCS, but at concentrations 298 much higher $\left(47-500 \mu \mathrm{g} \mathrm{L}^{-1}\right)$ than those used in this study or even typically observed in the 299 environment. Increased metabolic and heart rates have been observed in bivalves exposed to 300 pollutants (Bakhmet et al., 2009; Manachini et al., 2013), though some pollutants known to be 301 highly toxic, such as cadmium, did not alter heart rate or metabolic rate (Lannig et al., 2008). Due 302 to experimental limitations, it was not possible to measure behavior and resting metabolic rate 303 simultaneously for the same individual, as doing so would likely disrupt the animals' behavior.

304 Thus we were not able to directly compare these endpoints within the same individual.

305 Additionally, we did not examine whether TCS exposure reduced metabolic scope (i.e., the 306 difference between maximum metabolic rate and resting metabolic rate; Clarke and Pörtner, 307 2010). A reduction in metabolic scope may be impeding burrowing, though further 308 experimentation is needed to explicitly test this hypothesis.

309 Although we did not detect differences in resting metabolic rate, previous studies have 310 demonstrated that environmental stressors do not necessary alter all components of an organism's 311 energy budget, but rather result in complex energetic trade-offs (DuRant et al., 2007). At the 312 cellular level, protein abundance and mRNA expression data revealed induction of total-AMPK 313 at $900 \mathrm{ng} \mathrm{L}^{-1}$ TCS and increased AMPK-activity after $21 \mathrm{~d}$ exposure, indicating that TCS inhibits 314 ATP production or facilitates ATP depletion. Protective and repair mechanisms are energetically 315 demanding (Sokolova et al., 2012), thus increased AMPK activity is in accord with the many 316 studies describing oxidative stress, DNA damage, lysosomal membrane instability, and endocrine 317 disruption in mussels exposed to TCS (Binelli et al., 2009a,b,2011; Riva et al., 2012;

318 Falfushynska et al., 2014). Additionally, TCS may target mitochondria and impede ATP 319 production (Weatherly et al., In press), which would also cause AMPK activation. Taken as a 
320 whole, our data suggests that TCS alters energy homeostasis at the cellular level, which may

321 result in an energetic trade-off between activity (i.e., burrowing and movement) and repair.

322 We found marginal evidence for detoxification costs. GST enzyme activity increased,

323 and a similar trend was mirrored in the GST mRNA data, though is not significant $(\mathrm{p}=0.06)$.

324 Increased GST activity in response to TCS has been reported previously by Binelli et al. (2009a,

325 2011) at concentrations similar to those used in this study. Importantly, the greatest increase in

326 enzyme activity reported in other studies occurred within the initial $48 \mathrm{~h}$ of exposure, and GST

327 activity returned to baseline by $96 \mathrm{~h}$. In our study, we observed increases in GST levels after $4 \mathrm{~d}$,

328 but no effect on GST levels after $21 \mathrm{~d}$. We did not observe any difference in SOD levels, but as

329 with GST, prior studies observed increased SOD activity during the initial $72 \mathrm{~h}$ and a return to

330 baseline by $96 \mathrm{~h}$ (Binelli et al., 2011). Since prior studies saw a return to baseline after $4 \mathrm{~d}$ of

331 exposure, it is plausible that we only captured the GST response as it returned to baseline, and we

332 potentially missed any effect on SOD. By comparing results from acute exposure reported

333 elsewhere (Binelli et al., 2009b,2011) and our subchronic exposure reported here, it appears that

334 SOD and GST are important in the initial response to TCS exposure, but are not part of protective

335 strategies under subchronic conditions (Binelli et al., 2009b; Hinther et al., 2011).

336 Evaluating toxicity from an energetics perspective may be useful for establishing adverse

337 outcome pathways (Ankley et al., 2010) for toxicants that potentially target mitochondria;

338 however, several different methods exist for examining cellular energy stress and it is unclear

339 which methods are most sensitive to mitochondrial disruption. For instance, some studies have

340 focused on measuring ATP concentrations or ATP:ADP ratios (e.g., Dickinson et al., 2011), but

341 as we discussed elsewhere, such data might not capture energetic stress. Alternatively, De Coen

342 and Janssen (2003) proposed measuring concentrations of cellular macromolecules to determine

343 “cellular energy allocation", which indirectly assesses ATP consumption by assuming

344 energetically stressed animals will catabolize macromolecules to satisfy their energy needs. In our

345 case, we used AMPK because it has been mechanistically identified as an upstream regulator of 
346 macromolecule metabolism and is directly activated by slight decreases in ATP concentrations

347 (Hardie et al., 2006). Therefore, we propose that AMPK may be a valuable energetic biomarker

348 for use in ecotoxicological studies because it is sensitive to low concentrations of pollutants in

349 both controlled and field scenarios (see Goodchild et al., 2015), though further comparative

350 studies are needed to evaluate which methods are most informative.

351 Ultimately, adverse outcome pathways aim to make links between effects at multiple

352 levels of organization (Groh et al., 2015), thus in order for AMPK to be an informative

353 component of adverse outcome pathways, more evidence is needed that links AMPK activity with

354 effects at higher levels of organization. Previous studies have demonstrated linkages between

355 running endurance and AMPK activity in marine crustaceans following various types of

356 environmental stress, such as elevated water temperatures, low salinity conditions, and hypoxia

357 (Frederich et al., 2009; Jost et al., 2012). AMPK is also known to have a functional role of

358 accelerating ATP producing pathways in skeletal muscle during exercise (Hardie and Sakamoto,

359 2006). Nonetheless, further study examining the relationship between AMPK in muscle tissue

360 and mussel activity will strengthen the energetic link between cellular and whole-animal effects.

\section{5. CONCLUSION}

362 Exposure to environmentally relevant concentrations of TCS may result in a reallocation

363 of available energy. Behaviorally, mussels exposed to TCS were less likely to burrow and move,

364 which might reduce fitness in situ. Additionally, TCS exposure resulted in increased total-AMPK

365 protein and mRNA levels, along with an increase in AMPK-activity. Elevated AMPK levels

366 suggest that detoxification of TCS results in an energetically taxing situation. By pairing our

367 molecular and behavioral data, we speculate that TCS exposure may result in an energetic

368 tradeoff between detoxification and movement behaviors.

\section{ACKNOWLEDGEMENTS}

370 We thank I. Sokolova and R. Miller for offering their expertise, which greatly improved

371 this study. Additionally, we thank C. Whalen, G. Pelletier, and L. Bien for their assistance in data 
372 collection. We also appreciate the constructive critiques from two anonymous reviewers. Funding 373 support was provided through an NSF grant (NSF DGE-0841361) to S.Z. and a Maine SeaGrant 374 Project Development grant to M.F.

375 
377 Allen, D.C., Vaughn, C.C., 2009. Burrowing behavior of freshwater mussels in experimentally manipulated communities. Journal of the North American Benthological Society 28, 93 100.

380 Ankley, G.T., Bennett, R.S., Erickson, R.J., Hoff, D.J., Hornung, M.W., Johnson, R.D., Mount, D.R., Nichols, J.W., Russom, C.L., Schmieder, P.K., Serrrano, J.A., Tietge, J.E., Villeneuve, D.L., 2010. Adverse outcome pathways: a conceptual framework to support ecotoxicology research and risk assessment. Environmental Toxicology and Chemistry

Amyot, J.P., Downing, J.A., 1998. Locomotion in Elliptio complanata (Mollusca : Unionidae): a reproductive function? Freshwater Biology 39, 351-358. Pharmaceutical Compounds and Endocrine Disruptors in Municipal Wastewater Using Solid-Phase Microextraction and Gas Chromatography. Water Environment Research 81,

394 Bakhmet, I.N., Fokina, N.N., Nefedova, Z.A., Nemova, N.N., 2009. Physiological-biochemical properties of blue mussel Mytilus edulis adaptation to oil contamination. Environmental Monitoring and Assessment 155, 581-591. in treated municipal wastewater and river water. In: Kieth, L.H., JonesLepp, T.L.,

$400 \quad$ Symposium Series, pp. 97-123. 
401 Bedoux, G., Roig, B., Thomas, O., Dupont, V., Le Bot, B., 2012. Occurrence and toxicity of 402 antimicrobial triclosan and by-products in the environment. Environmental Science and $403 \quad$ Pollution Research 19, 1044-1065.

404 Bell, K.Y., Wells, M.J.M., Traexler, K.A., Pellegrin, M.L., Morse, A., Bandy, J., 2011. Emerging 405 Pollutants. Water Environment Research 83, 1906-1984.

406 Binelli, A., Cogni, D., Parolini, M., Riva, C., Provini, A., 2009a. Cytotoxic and genotoxic effects 407 of in vitro exposure to Triclosan and Trimethoprim on zebra mussel (Dreissena 408 polymorpha) hemocytes. Comparative Biochemistry and Physiology C-Toxicology \& $409 \quad$ Pharmacology 150, 50-56.

410 Binelli, A., Cogni, D., Parolini, M., Riva, C., Provini, A., 2009b. In vivo experiments for the 411 evaluation of genotoxic and cytotoxic effects of Triclosan in Zebra mussel hemocytes. $412 \quad$ Aquatic Toxicology 91, 238-244.

413 Binelli, A., Parolini, M., Pedriali, A., Provini, A., 2011. Antioxidant Activity in the Zebra Mussel 414 (Dreissena polymorpha) in Response to Triclosan Exposure. Water Air and Soil Pollution $415 \quad 217,421-430$.

416 Bowers, R., Sudomir, J.C., Kershner, M.W., de Szalay, F.A., 2005. The effects of predation and 417 unionid burrowing on bivalve communities in a Laurentian Great Lake coastal wetland. $418 \quad$ Hydrobiologia 545, 93-102.

419 Braby, C.E., Somero, G.N., 2006. Following the heart: temperature and salinity effects on heart 420 rate in native and invasive species of blue mussels (genus Mytilus). Journal of $421 \quad$ Experimental Biology 209, 2554-2566.

422 Bradford, M.M., 1976. Rapid and sensitive method for quantitation of microgram quantities of 423 protein utilizing principle of protein-dye binding. Analytical Biochemistry 72, 248-254.

424 Brown, J.H., Gillooly, J.F., Allen, A.P., Savage, V.M., West, G.B., 2004. Toward a metabolic 425 theory of ecology. Ecology 85, 1771-1789. 
426 Calow, P., 1989. Proximate and ultimate responses to stress in biological-systems. Biological $427 \quad$ Journal of the Linnean Society 37, 173-181.

428 Canesi, L., Ciacci, C., Lorusso, L.C., Betti, M., Gallo, G., Pojana, G., Marcomini, A., 2007.

429 Effects of Triclosan on Mytilus galloprovincialis hemocyte function and digestive gland

430 enzyme activities: Possible modes of action on non target organisms. Comparative

431 Biochemistry and Physiology C-Toxicology \& Pharmacology 145, 464-472.

432 Caraco, N.F., Cole, J.J., Strayer, D.L., 2006. Top-down control from the bottom: Regulation of

433 eutrophication in a large river by benthic grazing. Limnology and Oceanography 51, 664-

$434 \quad 670$

435 Carling, D., Clarke, P.R., Zammit, V.A., Hardie, D.G., 1989. Purification and characterization of

436 the amp-activated protein-kinase - copurification of acetyl-coa carboxylase kinase and 3-

437 hydroxy-3-methylglutaryl-coa reductase kinase-activities. European Journal of

$438 \quad$ Biochemistry 186, 129-136.

439 Carmi, N., Pinshow, B., Porter, W.P., Jaeger, J., 1992. Water and energy limitations on flight

440 duration in small migrating birds. Auk 109, 268-276.

441 Clarke, A., Portner, H.O., 2010. Temperature, metabolic power and the evolution of endothermy.

$442 \quad$ Biological Reviews 85, 703-727.

443 Cole, E.F., Quinn, J.L., 2014. Shy birds play it safe: personality in captivity predicts risk

444 responsiveness during reproduction in the wild. Biology Letters 10, 4.

445 Coogan, M.A., La Point, T.W., 2008. Snail bioaccumulation of triclocarban, triclosan, and

446 methyltriclosan in a North Texas, USA, stream affected by wastewater treatment plant

447 runoff. Environmental Toxicology and Chemistry 27, 1788-1793.

448 Cortez, F.S., Pereira, C.D.S., Aldo, R.S.B., Cesar, A., Choueri, R.B., Martini, G.D., Bohrer-

449 Morel, M.B., 2012. Biological effects of environmentally relevant concentrations of the

450 pharmaceutical Triclosan in the marine mussel Perna perna (Linnaeus, 1758).

451 Environmental Pollution 168, 145-150. 
452 Cox, D.R., 1972. Regression models and life-tables. Journal of the Royal Statistical Society

453 Series B-Statistical Methodology 34, 187-+.

454 De Coen, W.M., Janssen, C.R., 2003. The missing biomarker link: Relationships between effects

455 on the cellular energy allocation biomarker of toxicant-stressed Daphnia magna and

456 corresponding population characteristics. Environmental Toxicology and Chemistry 22,

$457 \quad 1632-1641$.

458 Dhillon, G.S., Kaur, S., Pulicharla, R., Brar, S.K., Cledon, M., Verma, M., Surampalli, R.Y.,

459 2015. Triclosan: Current Status, Occurrence, Environmental Risks and Bioaccumulation

460 Potential. International Journal of Environmental Research and Public Health 12, 5657-

4615684.

462 Dickinson, G.H., Ivanina, A.V., Matoo, O.B., Portner, H.O., Lannig, G., Bock, C., Beniash, E.,

463 Sokolova, I.M., 2012. Interactive effects of salinity and elevated CO2 levels on juvenile

464 eastern oysters, Crassostrea virginica. Journal of Experimental Biology 215, 29-43.

465 DuRant, S.E., Hopkins, W.A., Talent, L.G., 2007. Energy acquisition and allocation in an

466 ectothermic predator exposed to a common environmental stressor. Comparative

467 Biochemistry and Physiology C-Toxicology \& Pharmacology 145, 442-448.

468 Falfushynska, H.I., Gnatyshyna, L.L., Osadchuk, O.Y., Farkas, A., Vehovszky, A., Carpenter,

469 D.O., Gyori, J., Stoliar, O.B., 2014. Diversity of the molecular responses to separate

470 wastewater effluents in freshwater mussels. Comparative Biochemistry and Physiology

471 C-Toxicology \& Pharmacology 164, 51-58.

472 Flynn, K., Wedin, M.B., Bonventre, J.A., Dillon-White, M., Hines, J., Weeks, B.S., Andre, C.,

473 Schreibman, M.P., Gagne, F., 2013. Burrowing in the freshwater mussel Elliptio

474 complanata is sexually dimorphic and feminized by low levels of atrazine. Journal of

475 Toxicology and Environmental Health-Part a-Current Issues 76, 1168-1181.

476 Forbes, V.E., Palmqvist, A., Bach, L., 2006. The use and misuse of biomarkers in ecotoxicology.

477 Environmental Toxicology and Chemistry 25, 272-280. 
478 Frederich, M., O'Rourke, M.R., Furey, N.B., Jost, J.A., 2009. AMP-activated protein kinase

479 (AMPK) in the rock crab, Cancer irroratus: an early indicator of temperature stress.

$480 \quad$ Journal of Experimental Biology 212, 722-730.

481 Gatidou, G., Vassalou, E., Thomaidis, N.S., 2010. Bioconcentration of selected endocrine

482 disrupting compounds in the Mediterranean mussel, Mytilus galloprovincialis. Marine

$483 \quad$ Pollution Bulletin 60, 2111-2116.

484 Goodchild, C.G., Frederich, M., Zeeman, S.I., 2015. AMP-activated protein kinase is a biomarker 485 of energetic status in freshwater mussels exposed to municipal effluents. The Science of 486 the Total Environment 512-513, 201-209.

487 Gough, H.M., Landis, A.M.G., Stoeckel, J.A., 2012. Behaviour and physiology are linked in the responses of freshwater mussels to drought. Freshwater Biology 57, 2356-2366.

Guevelou, E., Huvet, A., Sussarellu, R., Milan, M., Guo, X.M., Li, L., Zhang, G.F., Quillien, V., Daniel, J.Y., Quere, C., Boudry, P., Corporeau, C., 2013. Regulation of a truncated isoform of AMP-activated protein kinase alpha (AMPK alpha) in response to hypoxia in the muscle of Pacific oyster Crassostrea gigas. Journal of Comparative Physiology BBiochemical Systemic and Environmental Physiology 183, 597-611. Toxicology, The Basic Science of Poisons, McGraw-Hill Education, New York, pp. 49122.

Groh, K.J., Carvalho, R.N., Chipman, J.K., Denslow, N.D., Halder, M., Murphy, C.A., Roelofs, D., Rolaki, A., Schirmer, K., Watanabe, K.H., 2015. Development and application of the adverse outcome pathway framework for understanding and predicting chronic toxicity: I. Challenges and research needs in ecotoxicology. Chemosphere 120, 764-777.

501 Habig, W.H., Pabst, M.J., Jakoby, W.B., 1974. Glutathione s-transferases - first enzymatic step in 502 mercapturic acid formation. Journal of Biological Chemistry 249, 7130-7139. 
503 Harada, A., Komori, K., Nakada, N., Kitamura, K., Suzuki, Y., 2008. Biological effects of PPCPs

504 on aquatic lives and evaluation of river waters affected by different wastewater treatment

$505 \quad$ levels. Water Science and Technology 58, 1541-1546.

506 Hardie, D.G., 2007. AMP-activated/SNF1 protein kinases: conserved guardians of cellular

507 energy. Nature Reviews Molecular Cell Biology 8, 774-785.

508 Hardie, D.G., Hawley, S.A., Scott, J., 2006. AMP-activated protein kinase - development of the

509 energy sensor concept. Journal of Physiology-London 574, 7-15.

510 Hardie, D.G., Sakamoto, K., 2006. AMPK: A key sensor of fuel and energy status in skeletal

$511 \quad$ muscle. Physiology 21, 48-60.

512 Hazelton, P.D., Du, B.W., Haddad, S.P., Fritts, A.K., Chambliss, C.K., Brooks, B.W., Bringolf,

513 R.B., 2014. Chronic fluoxetine exposure alters movement and burrowing in adult

$514 \quad$ freshwater mussels. Aquatic Toxicology 151, 27-35.

515 Heidebrecht, F., Heidebrecht, A., Schulz, I., Behrens, S.E., Bader, A., 2009. Improved

516 semiquantitative Western blot technique with increased quantification range. Journal of

517 Immunological Methods 345, 40-48.

518 Hinther, A., Bromba, C.M., Wulff, J.E., Helbing, C.C., 2011. Effects of Triclocarban, Triclosan,

519 and Methyl Triclosan on Thyroid Hormone Action and Stress in Frog and Mammalian

$520 \quad$ Culture Systems. Environmental Science \& Technology 45, 5395-5402.

521 Huggett, J., Dheda, K., Bustin, S., Zumla, A., 2005. Real-time RT-PCR normalisation; strategies

522 and considerations. Genes and Immunity 6, 279-284.

523 Jost, J.A., Keshwani, S.S., Abou-Hanna, J.J., 2015. Activation of AMP-activated protein kinase

524 in response to temperature elevation shows seasonal variation in the zebra mussel,

525 Dreissena polymorpha. Comparative Biochemistry and Physiology a-Molecular \&

526 Integrative Physiology 182, 75-83. 
527 Jost, J.A., Podolski, S.M., Frederich, M., 2012. Enhancing thermal tolerance by eliminating the 528 pejus range: a comparative study with three decapod crustaceans. Marine Ecology

529 Progress Series 444, 263-274.

530 Kolpin, D.W., Furlong, E.T., Meyer, M.T., Thurman, E.M., Zaugg, S.D., Barber, L.B., Buxton,

531 H.T., 2002. Response to Comment on,"Pharmaceuticals, hormones, and other organic

532 wastewater contaminants in US streams, 1999-2000: A national reconnaissance".

Environmental Science \& Technology 36, 4007-4008.

534 Kooijman, S.A.L.M., Baas, J., Bontje, D., Broerse, M., van Gestel, C.A.M., Jager, T., 2009.

535 Ecotoxicological applications of dynamic energy budget theory. In: Devillers, J. (Ed.)

536 Ecotoxicology Modeling, Emerging Topics in Ecotoxicology, Springer Science \&

537 Business Media, Amsterdam, pp. 237-259.

538 Kookana, R.S., Shareef, A., Fernandes, M.B., Hoare, S., Gaylard, S., Kumar, A., 2013.

539 Bioconcentration of triclosan and methyl-triclosan in marine mussels (Mytilus

540 galloprovincialis) under laboratory conditions and in metropolitan waters of Gulf St

541 Vincent, South Australia. Marine Pollution Bulletin 74, 66-72.

542 Lannig, G., Cherkasov, A.S., Portner, H.O., Bock, C., Sokolova, I.M., 2008. Cadmium-dependent

543 oxygen limitation affects temperature tolerance in eastern oysters (Crassostrea virginica

544 Gmelin). American Journal of Physiology-Regulatory Integrative and Comparative

$545 \quad$ Physiology 294, R1338-R1346.

546 Loayza-Muro, R., Elias-Letts, R., 2007. Responses of the mussel Anodontites trapesialis

547 (Unionidae) to environmental stressors: Effect of $\mathrm{pH}$, temperature and metals on filtration $548 \quad$ rate. Environmental Pollution 149, 209-215.

549 Lohrer, A.M., Thrush, S.F., Gibbs, M.M., 2004. Bioturbators enhance ecosystem function

550 through complex biogeochemical interactions. Nature 431, 1092-1095.

551 Maltby, L., 1999. Studying stress: The importance of organism-level responses. Ecological

$552 \quad$ Applications 9, 431-440. 
553 Manachini, B., Arizza, V., Rinaldi, A., Montalto, V., Sara, G., 2013. Eco-physiological response 554 of two marine bivalves to acute exposition to commercial Bt-based pesticide. Marine $555 \quad$ Environmental Research 83, 29-37.

556 Matozzo, V., Formenti, A., Donadello, G., Marin, M.G., 2012a. A multi-biomarker approach to 557 assess effects of Triclosan in the clam Ruditapes philippinarum. Marine Environmental $558 \quad$ Research 74, 40-46.

559 Matozzo, V., Devoti, A.C., Marin, M.G., 2012b. Immunotoxic effects of triclosan in the clam $560 \quad$ Ruditapes philippinarum. Ecotoxicology 21, 66-74.

561 McAvoy, D.C., Schatowitz, B., Jacob, M., Hauk, A., Eckhoff, W.S., 2002. Measurement of

562 triclosan in wastewater treatment systems. Environmental Toxicology and Chemistry 21, $563 \quad 1323-1329$.

564 McCord, J.M., Fridovic.I, 1969. Superoxide dismutase an enzymic function for erythrocuprein 565 (hemocuprein). Journal of Biological Chemistry 244, 6049-\&.

566 McEwen, B.S., Wingfield, J.C., 2003. The concept of allostasis in biology and biomedicine.

$567 \quad$ Hormones and Behavior 43, 2-15.

568 McMahon, R.F., Bogan, A.E., 2001. Mollusca: Bivalvia. In: Throp, J.P., Covich, A.P. (Eds.), 569 Ecology and classification of North American freshwater invertebrates, Academic Press, $570 \quad$ New York, p 331-429.

571 Mearns, A.J., Reish, D.J., Oshida, P.S., Ginn, T., Rempel-Hester, M.A., Arthur, C., Rutherford, 572 N., 2013. Effects of Pollution on Marine Organisms. Water Environment Research 85, $573 \quad 1828-1933$.

574 Milligan, C.L., 1996. Metabolic recovery from exhaustive exercise in rainbow trout. Comparative 575 Biochemistry and Physiology a-Physiology 113, 51-60.

576 Murray, K.E., Thomas, S.M., Bodour, A.A., 2010. Prioritizing research for trace pollutants and 577 emerging contaminants in the freshwater environment. Environmental Pollution 158, $578 \quad 3462-3471$. 
579 Palenske, N.M., Nallani, G.C., Dzialowski, E.M., 2010. Physiological effects and

580 bioconcentration of triclosan on amphibian larvae. Comparative Biochemistry and

$581 \quad$ Physiology C-Toxicology \& Pharmacology 152, 232-240.

582 Perez, J.M.M., Pascue, J., 2013. Image Processing with ImageJ. Packt Publishing Ltd,

583 Birmingham.

584 Richards, J.G., Heigenhauser, G.J.F., Wood, C.M., 2002. Lipid oxidation fuels recovery from

585 exhaustive exercise in white muscle of rainbow trout. American Journal of Physiology-

586 Regulatory Integrative and Comparative Physiology 282, R89-R99.

587 Riva, C., Cristoni, S., Binelli, A., 2012. Effects of triclosan in the freshwater mussel Dreissena

$588 \quad$ polymorpha: A proteomic investigation. Aquatic Toxicology 118, 62-71.

589 Romero, L.M., Dickens, M.J., Cyr, N.E., 2009. The reactive scope model - A new model

590 integrating homeostasis, allostasis, and stress. Hormones and Behavior 55, 375-389.

591 Sabaliunas, D., Webb, S.F., Hauk, A., Jacob, M., Eckhoff, W.S., 2003. Environmental fate of

592 Triclosan in the River Aire Basin, UK. Water Research 37, 3145-3154.

593 Selye, H., 1950. Stress and the general adaptation syndrome. British Medical Journal 1, 1383-

$594 \quad 1392$.

595 Sokolova, I.M., Frederich, M., Bagwe, R., Lannig, G., Sukhotin, A.A., 2012. Energy homeostasis

596 as an integrative tool for assessing limits of environmental stress tolerance in aquatic

597 invertebrates. Marine Environmental Research 79, 1-15.

598 Spooner, D.E., Vaughn, C.C., 2012. Species' traits and environmental gradients interact to govern

599 primary production in freshwater mussel communities. Oikos 121, 403-416.

600 TSCA Chemical Substances Inventory, 2003. Potential endocrine disrupting organic chemicals in

601 treated municipal wastewater and river water. U.S. Environmental Protection Agency,

602 Washington D.C. 
603 Tsomides, L., Danielson, T., Meidel, S., 2013. Rivers and Streams Module. In: Kuhns, M., (Ed.), 604 Surface Water Ambient Toxics Monitoring Program 2012. Maine Department of 605 Environmental Protection. Augusta, ME.

606 Vaughn, C.C., Hakenkamp, C.C., 2001. The functional role of burrowing bivalves in freshwater 607 ecosystems. Freshwater Biology 46, 1431-1446.

608 Waller, D.L., Gutreuter, S., Rach, J.J., 1999. Behavioral responses to disturbance in freshwater 609 mussels with implications for conservation and management. Journal of the North 610 American Benthological Society 18, 381-390.

611 Weatherly, L.M., Shim, J., Hashmi, H.N., Kennedy, R.H., Hess, S.T., Gosse, J.A., In press. 612 Antimicrobial Agent Triclosan is a Proton Ionophore Uncoupler of Mitochondria in 613 Living Rat and Human Mast Cells and in Primary Human Keratinocytes. Journal of $614 \quad$ Applied Toxicology.

615 
616 Tables:

617 Table 1. Specific primers for Elliptio complanata for RT-PCR analysis of relative mRNA

618 concentrations of respective gene targets.

\begin{tabular}{|lll|}
\hline Target & Primer & Nucleotide Sequence \\
\hline \multirow{2}{*}{ AMPK $\gamma$} & F & 5'- GAA GTG GAG AGA GGA ATT GAA GG- 3' \\
& $\mathrm{R}$ & 5'- TGT GGA CAT GGT GTT GGA TTA G- 3' \\
\hline \multirow{2}{*}{ HSP70 } & F & 5'- GGT GTG TTG ATC CAG GTC TAT G -3' \\
& $\mathrm{R}$ & 5'- GCT GGT GGA ATT CCC TGT AA -3' \\
\hline \multirow{2}{*}{ SOD } & $\mathrm{F}$ & 5'- CAA CCC TAG CAA GCA GGA A -3' \\
& $\mathrm{R}$ & 5'- CAT GTG CCA CTC CAT CAT CT -3' \\
\hline \multirow{2}{*}{ GST } & $\mathrm{F}$ & 5'- GCT GAG GTA CTT GGG AAG AAA G -3' \\
& $\mathrm{R}$ & 5'- AGC AAG TCG ATA GTC CTC CA -3' \\
\hline
\end{tabular}

619

620 Table 2. Cox proportional hazard model describing the likelihood of burrowing and movement

621 behaviors following $21 \mathrm{~d}$ exposure to triclosan. Model outputs are odds ratios relative to the

622 control group. Values $<1$ indicate diminished likelihood of a behavior occurring. Bolded values

623 indicate $\mathrm{p}<0.05$.

624

\begin{tabular}{lll}
\hline & Burrowing & Moving \\
\hline $300 \mathrm{ng} / \mathrm{L}$ & $0.68(\mathrm{p}=0.50)$ & $0.60(\mathrm{p}=0.36)$ \\
$600 \mathrm{ng} / \mathrm{L}$ & $0.47(\mathrm{p}=0.19)$ & $0.51(\mathrm{p}=0.23)$ \\
$900 \mathrm{ng} / \mathrm{L}$ & $\mathbf{0 . 2 8}(\mathbf{p}=\mathbf{0 . 0 3})$ & $\mathbf{0 . 2 3}(\mathbf{p}=\mathbf{0 . 0 2})$ \\
\hline
\end{tabular}

625

626 
627 Figure Legends:

628 Fig. 1. Burrowing and movement performance of Elliptio complanata after $21 \mathrm{~d}$ exposure to

629 nominal concentrations of triclosan. (A) Time until burrowing. (B) Number of mussels that were

630 inactive, burrowed only, or relocated within treatment groups ( $n=10$ per treatment); none of the

631 mussels in the control or $300 \mathrm{ng} \mathrm{L}^{-1}$ group remained inactive.

632

633 Fig. 2. (A) Total-AMPK, (B) AMPK-activity, and (C) HSP70 protein abundance in Elliptio

634 complanta after 4 (gray bars) and 21 (white bars) d exposures to nominal concentrations of

635 triclosan. Representative western blot panels are displayed above respective proteins. Data are

636 normalized to set the data for control group to 1 . * denotes statistical significance $(\mathrm{p}<0.05)$

637 compared to relative control. Mean \pm S.E., $n=5$ per treatment.

638

639 Fig. 3. GST (A) and SOD (B) enzyme activity in Elliptio complanta after 4 (gray bars) and 21

640 (white bars) d exposure to nominal concentrations of triclosan. * denotes statistical significance

$641(\mathrm{p}<0.05)$ compared to relative control. Mean \pm S.E., $n=5$ per treatment.

642

643 Fig. 4. mRNA expression for AMPK $\gamma$ (A), HSP70 (B), SOD (C), and GST (D) in Elliptio

644 complanata after 4 (gray bars) and 21 (white bars) d exposures to nominal concentrations of

645 triclosan. Data are normalized to set the data for control group to 1. No treatments achieved

646 statistical significance $(\mathrm{p}<0.05)$ compared to relative control; however, \# denotes groups that

647 approached significance $(\mathrm{p}<0.10)$. Mean \pm S.E., $n=5$ per treatment.

648

649

650

651

652 
653 Supplementary Figure Legends:

654 Fig. S1. Resting metabolic rate measured by oxygen consumption in Elliptio complanata after 4 655 and $21 \mathrm{~d}$ of exposure to nominal concentrations of triclosan (mean \pm S.E., $n=6$ per treatment).

656

657 Fig. S2. Heart rate in Elliptio complanata after 4 and $21 \mathrm{~d}$ exposure to nominal concentrations of 658 triclosan (mean \pm S.E., $n=7$ per treatment).

659 

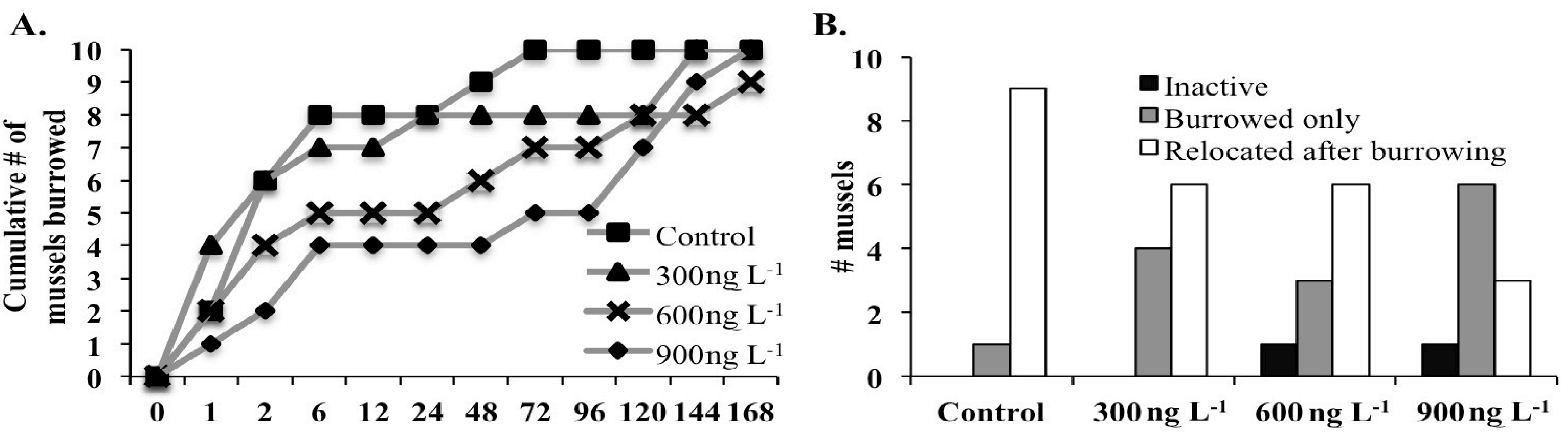

Time (h) 
Figure 2

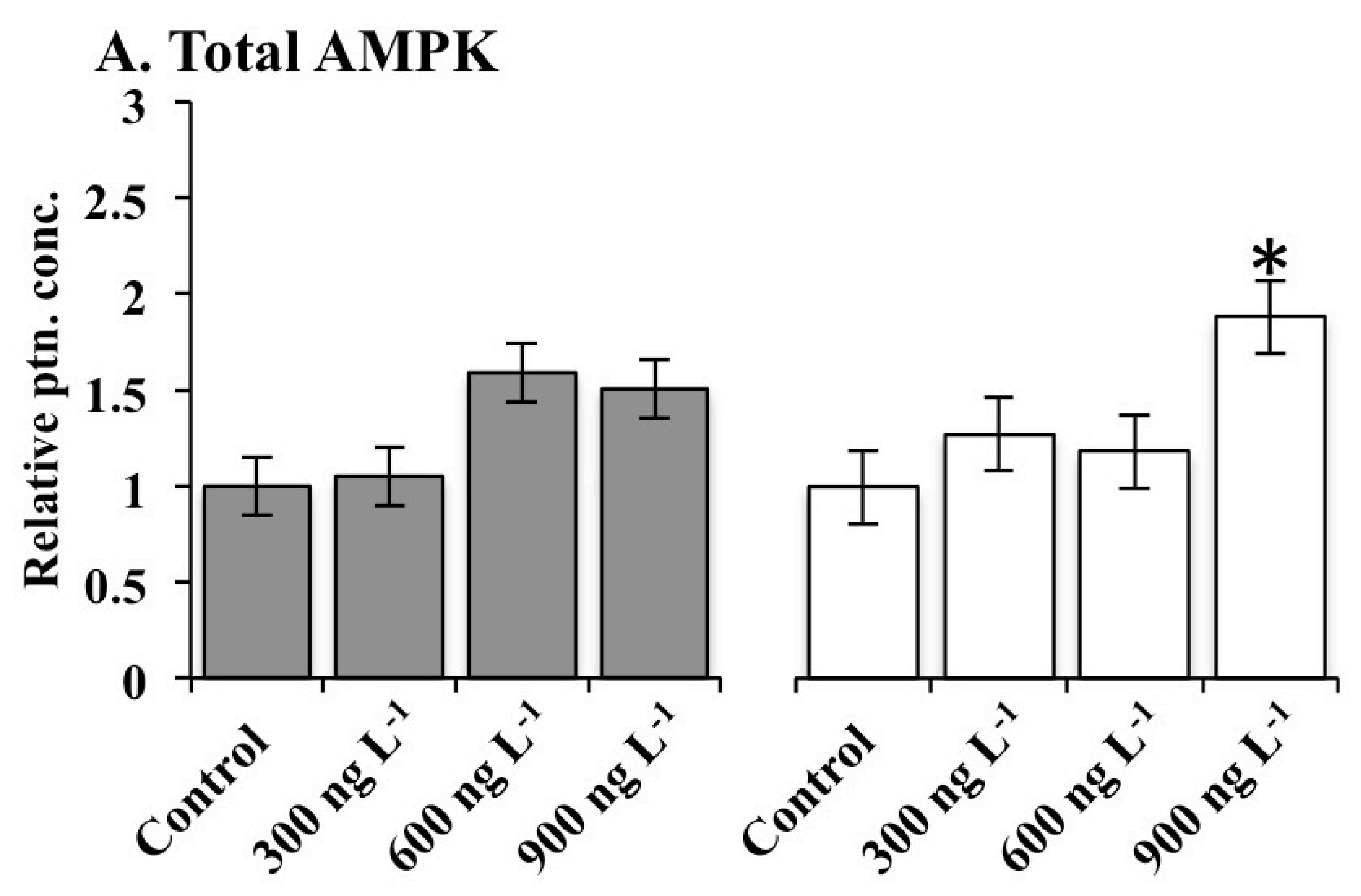

B. AMPK Activity

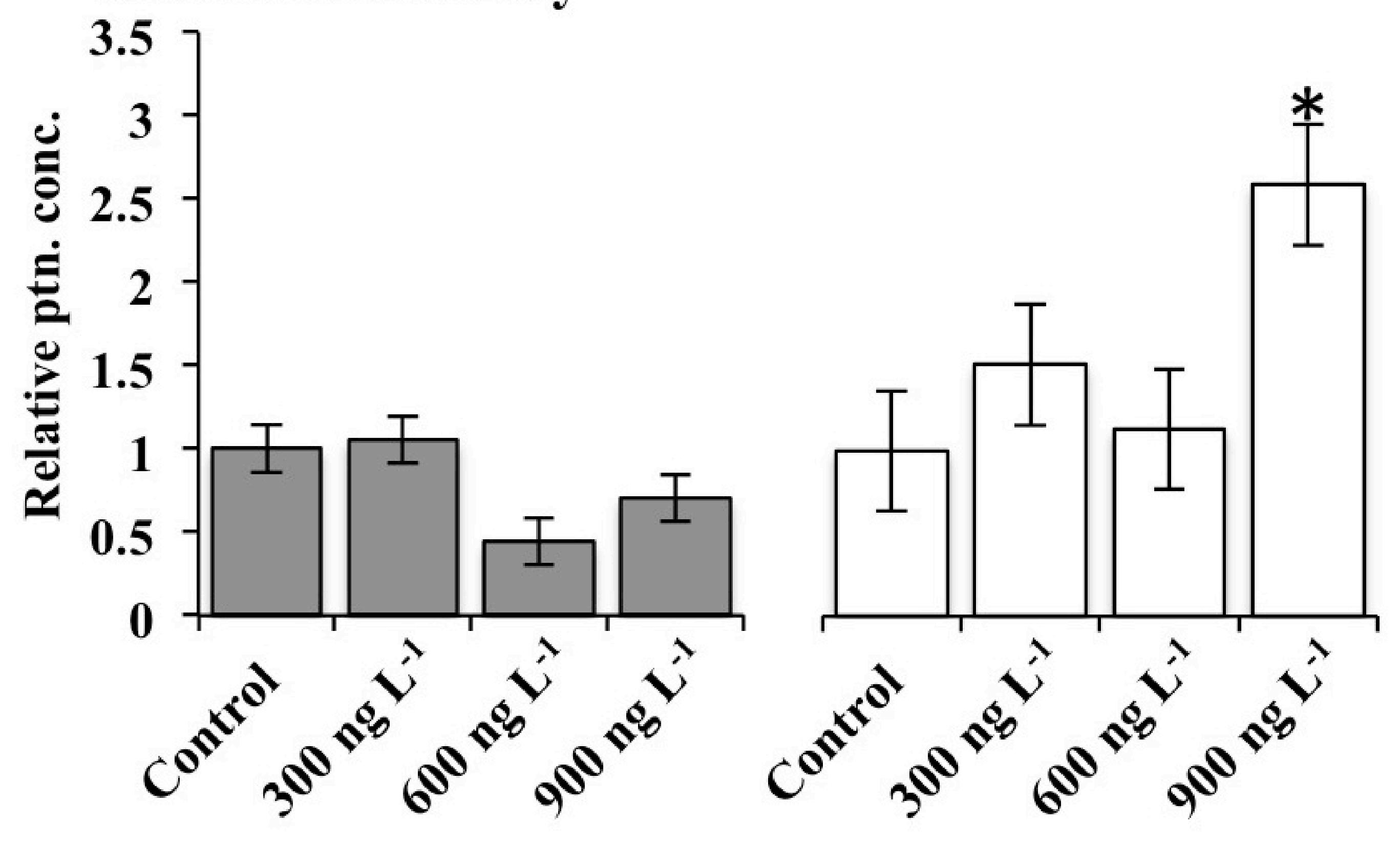

C. HSP70
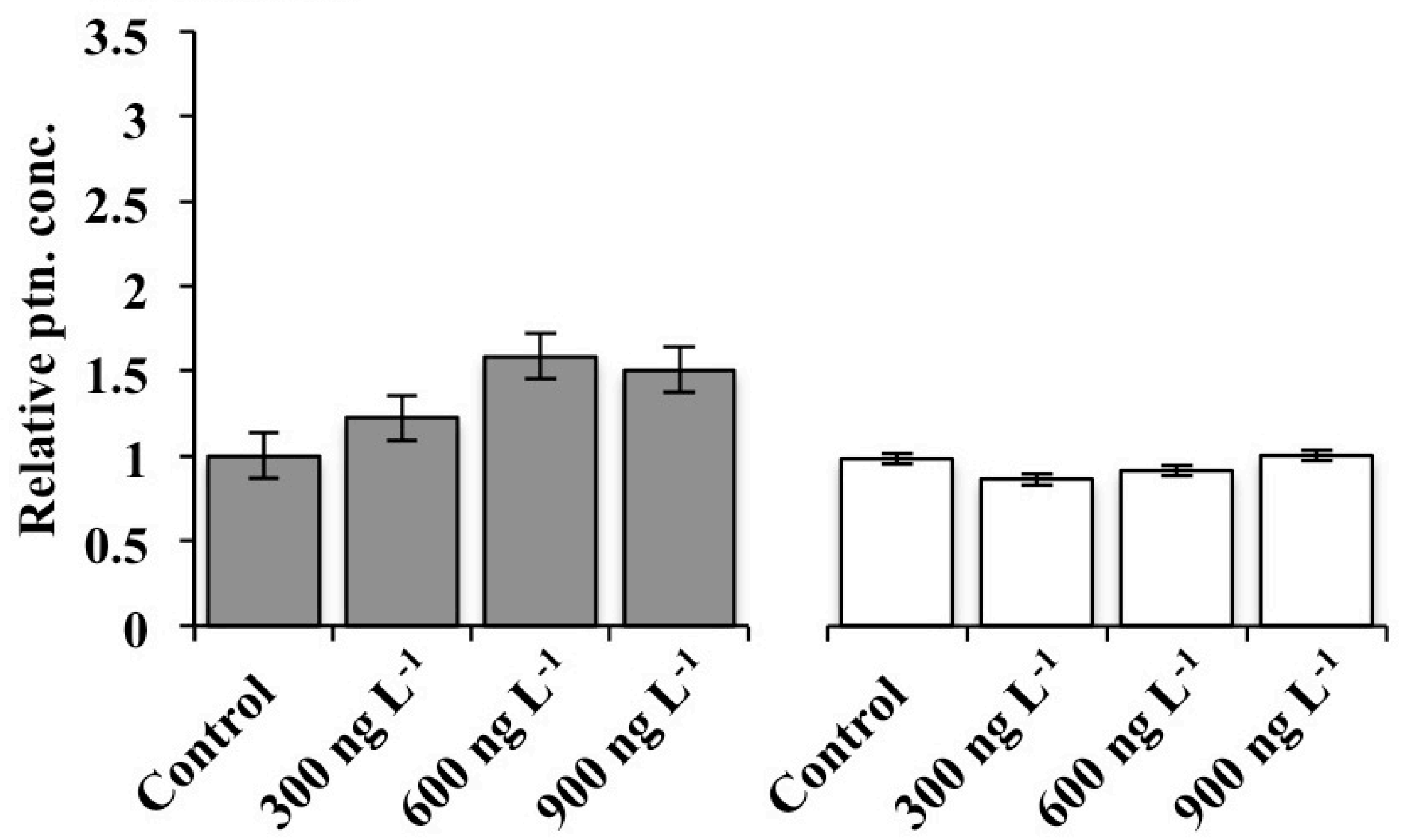

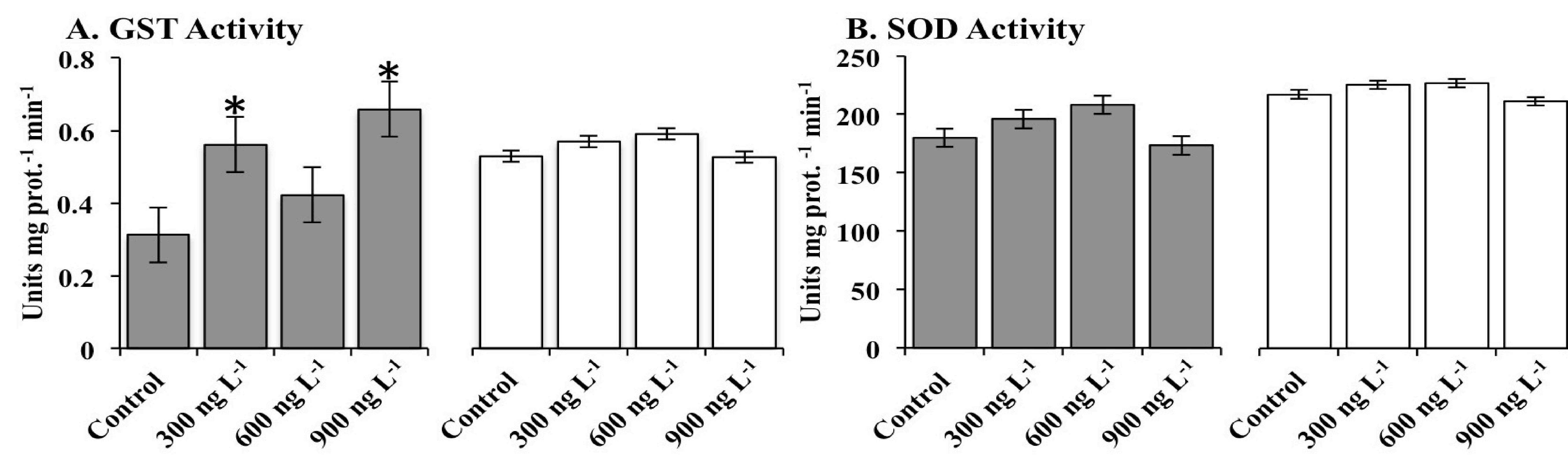
Figure 4
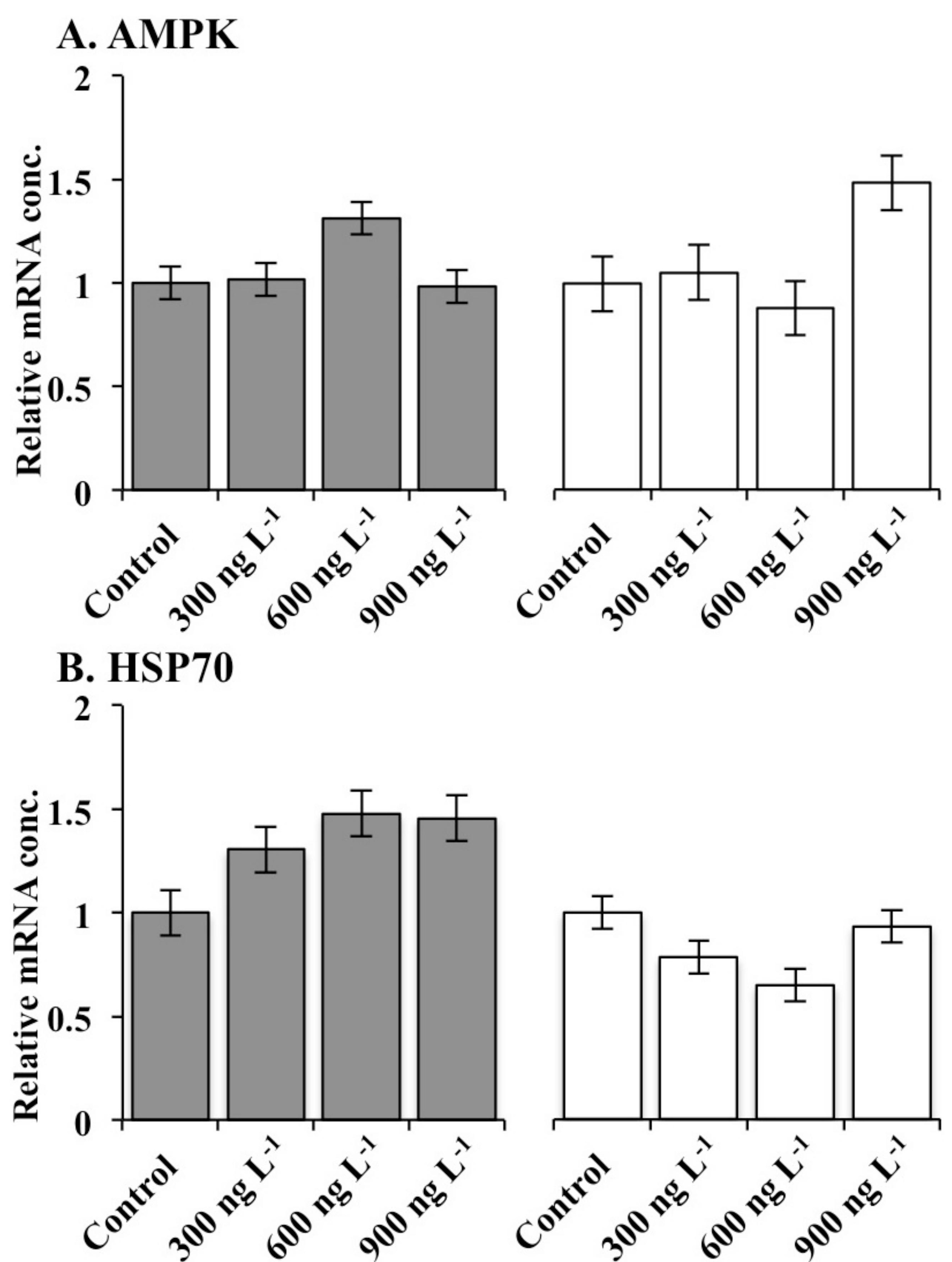

\section{GST}
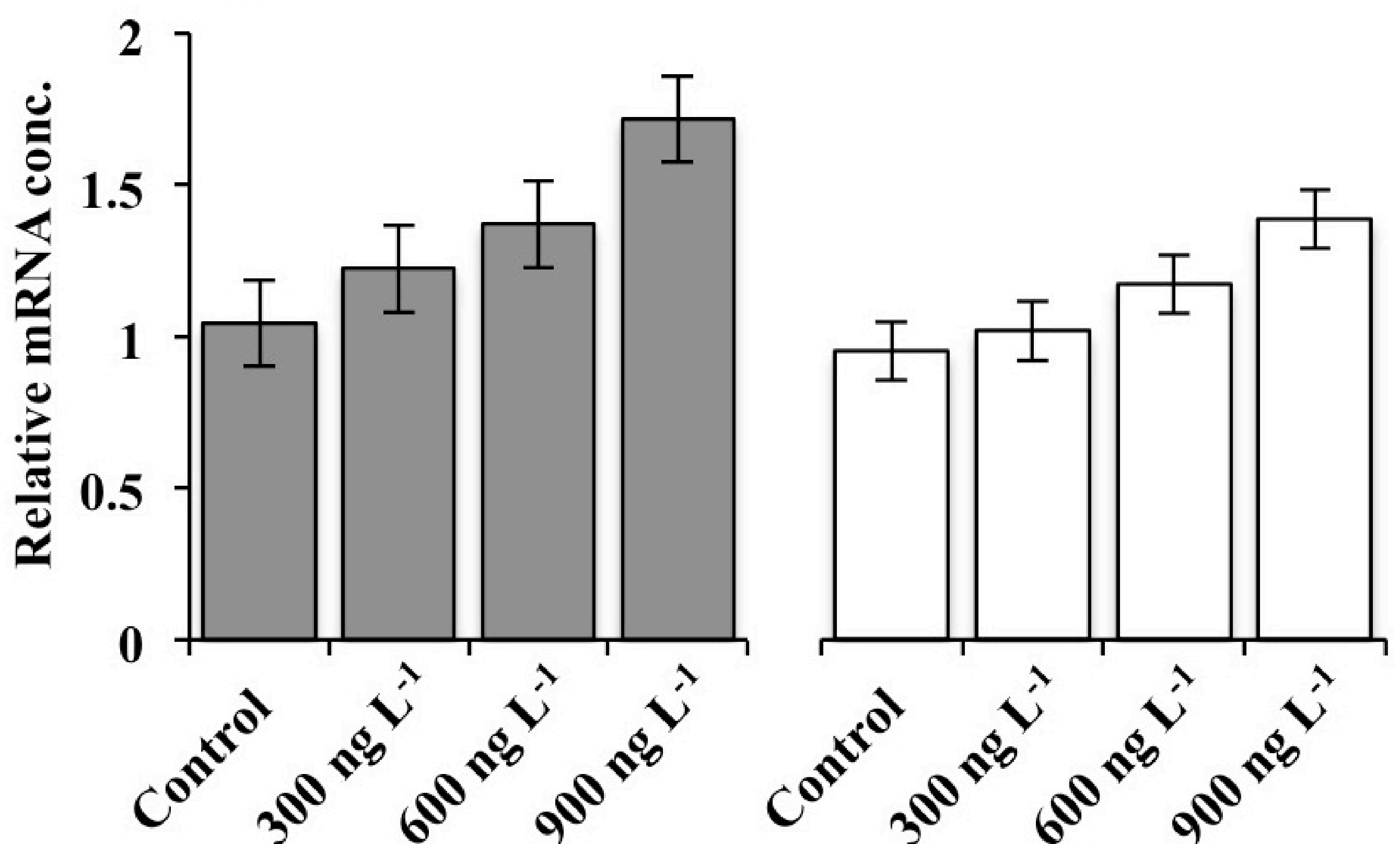

\section{SOD}
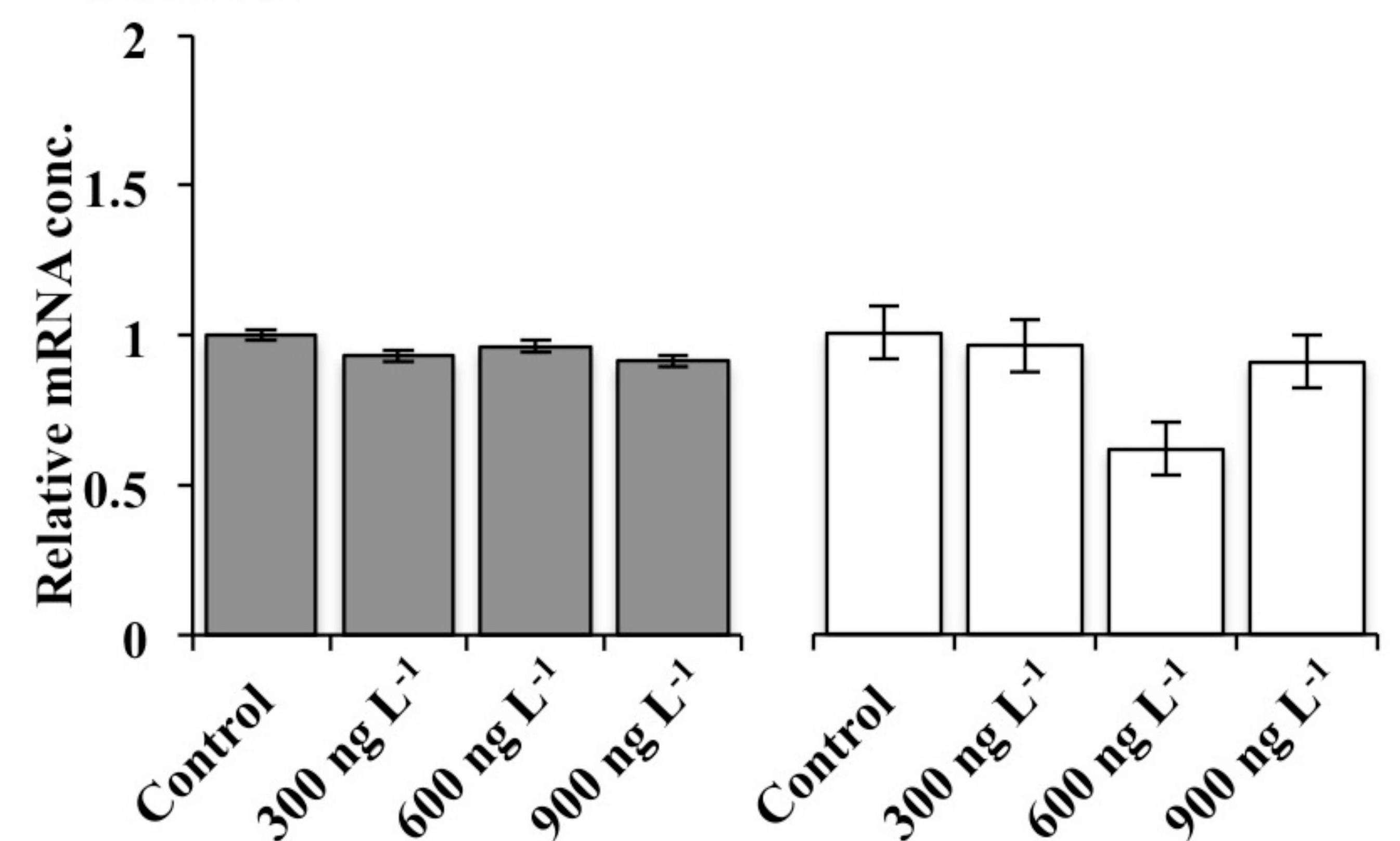